\title{
BRUNO PRIMA
}

TUTELA PROVISÓRIA POLÊMICAS QUANTO AO PROCEDIMENTO, ESTABILIDADE e COISA JULGADA (CPC/2015, ART. 294 e ss)

MONOGRAFIA

DEPARTAMENTO DE DIREITO PROGRAMA DE PÓS-GRADUAÇÃO EM DIREITO PROCESSUAL CIVIL

RIO DE JANEIRO

12 DE JULHO DE 2017 


\title{
TUTELA PROVISÓRIA \\ POLÊMICAS QUANTO AO PROCEDIMENTO, ESTABILIDADE e COISA JULGADA \\ (CPC/2015, ART. 294 e ss)
}

$$
\text { por }
$$

\author{
BRUNO PRIMA
}

ORIENTADOR(A): FIRLY NASCIMENTO FILHO

2017 
PONTIFÍCIA UNIVERSIDADE CATÓLICA DO RIO DE JANEIRO

RUA MARQUÊS DE SÃO VICENTE, 225 - CEP 22453-900 RIO

DE JANEIRO - BRASIL

\section{TUTELA PROVISÓRIA \\ POLÊMICAS QUANTO AO PROCEDIMENTO, ESTABILIDADE e COISA JULGADA (CPC/2015, ART. 294 e ss)}

por

\section{BRUNO PRIMA}

Monografia apresentada ao Departamento de Direito da Pontifícia Universidade Católica do Rio de Janeiro (PUC-Rio) para a obtenção do Certificado de conclusão do curso de PósGraduação de Direito Processual Civil - Turma XVII.

Rio de Janeiro

12/07/2017

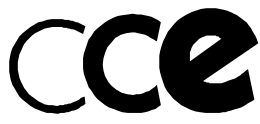

COORDENAÇÃO

CENTRAL DE

EXTENSÃO 


\section{Dedicatória}

Dedico o presente trabalho monográfico aos meus pais, que são meus modelos de moral, ética e justiça. 


\section{Resumo}

O presente trabalho versa sobre o novo instituto da Tutela Provisória vigente no ordenamento jurídico brasileiro, o qual é regido pelo Código de Processo Civil de 2015. A visão exposta tem por base o esclarecimento quanto aos requisitos, características, efeitos, métodos e aplicação mais especificamente a respeito das Tutelas de Urgência e Evidência, destacando as inconsistências procedimentais contidas na Tutela de urgência requerida em carácter antecedente, as quais, por certo, influenciam na obtenção da segurança jurídica buscada pelo legislador. Também é abordado neste trabalho monográfico o aspecto relativo à estabilidade das decisões e sua diferenciação com a Coisa Julgada, havendo uma delimitação entre as suas semelhanças e diferenças, notadamente quando o assunto abordado é a Tutela Provisória.

Palavras chaves: Tutela Provisória. Urgência. Evidência. Estabilidade. Coisa Julgada. 


\section{Sumário}

\section{Dedicatória}

Resumo

Introdução

Capítulo 1 - Da Evolução da Tutela Provisória

Capítulo 2 - Conceitos 9

2.1 - Conceito da Tutela Provisória 9

2.2 - Conceito da Tutela Definitiva 10

2.2 - Conceitos de Provisório / Referido / Temporário 12

Capítulo 3 - Aspectos Gerais da Tutela Provisória 15

3.1 - Características 15

3.2 - Espécies 16

3.3 - Regime Jurídico (CPC,/2015, art. 294) 16

3.4 - Incidental e Antecedente 18

3.5 - Cabimento 20

3.6 - Na Sentença e em Grau de Recurso 21

3.7 - Precariedade 24

3.8 - Do Recurso Cabível 24

3.9 - Da Eficácia da Decisão 26

Capítulo 4 - Da Tutela de Urgência 27

4.1 - Regramento 27

4.2 - Do Procedimento 28

4.2.1 - Incidental 28

4.2.2 - Antecedente 29 
4.2.2.1 - Das Inconsistências Procedimentais (Crítica ao Sistema) 32

4.2.2.2 - Estabilização x Coisa Julgada 36

4.2.3 - Cautelar em Caráter Antecedente 38

Capítulo 5 - Da Tutela de Evidência 39

5.1 - Regramento e Características $\quad 39$

Considerações finais $\quad 43$

$\begin{array}{ll}\text { Bibliografia } & 44\end{array}$ 


\section{Introdução}

O presente trabalho monográfico tem por escopo analisar o "microssistema" das Tutelas Provisórias implementado com o advento do Código de Processo Civil de 2015 (Lei n. ${ }^{\circ}$ 13.105/2015), evidenciando as mudanças ocorridas do antigo sistema jurídico conduzido pelo Código de Processo Civil de 1973 (Lei n. ${ }^{\circ}$ 5.869/1973), assim como o estudo pormenorizado das implicações jurídicas ocorridas com esse novo instituto.

Será, ainda, analisado o efeito do instituto da estabilidade em determinadas circunstâncias, bem como da coisa julgada, fazendo-se um comparativo a respeito das suas diferenças e incongruências.

Nesse contexto, o presente trabalho exporá o procedimento como um todo, identificando algumas polêmicas relativas aos prazos e consequências, que somente se pacificarão ao longo do tempo através da tão "sonhada" uniformização das decisões.

E, a partir da análise de hipóteses fáticas, se evidenciará que o supracitado "microssistema" da Tutela Provisória, apesar de significar um grande avanço para a comunidade dos processualistas civis brasileiros, ainda carece de aperfeiçoamento.

Afinal: "A ciência nunca resolve um problema sem criar pelo menos outros dez". (George Bernard Shaw) 


\section{Capítulo 1. DA EVOLUÇÃO DA TUTELA PROVISÓRIA}

O antigo sistema processual civil, conduzido pelo Código de Processo Civil de 1973 (“CPC/73”), antes da reforma ocorrida em 1994, previa a disposição da tutela provisória em 2 (duas) classificações: satisfativa e cautelar.

Tratando-se da satisfativa, o CPC/73 previa sua aplicação apenas em determinados procedimentos especiais, quais sejam:

(i) ação de depósito (Art. 901);

(ii) embargos de terceiro (Art. 1.046);

(iii) ações possessórias (Art. 920);

(iv) etc.

Observa-se que o instituto da tutela provisória satisfativa já existia, mas era tratado como algo excepcional, previsto em apenas alguns dispositivos específicos (procedimentos especiais).

Já no que tange à tutela provisória cautelar prevista no CPC/73, diferentemente da tutela provisória satisfativa, ela era considerada "atípica", possibilitando o seu requerimento para todo e qualquer caso que se enquadrasse aos seus requisitos legais.

Noutras palavras, a tutela provisória cautelar existente até então afigurase importante instrumento para pleitear qualquer direito à cautela, o que acabou sendo distorcido na prática forense, justamente pela inexistência de tutela provisória satisfativa de forma geral. 
Isto é, o que se formou durante mais de 20 (vinte) anos de prática forense foram os pedidos e decisões fundadas na regra das cautelares (assegurar o direito material), mas com nítido caráter satisfativo (direito propriamente dito), surgindo-se as conhecidas "cautelares satisfativas".

Como exemplo, é possível citar as cautelares de sustação de protesto e separação de corpus.

Tal aspecto, - em breves parênteses (crítica ao sistema) -, trouxe ônus aos advogados e uma consequência ao judiciário, pois, de acordo com o antigo sistema (CPC/73, art. 804) os autores dessas "cautelares satisfativas" deveriam ingressar com a ação principal, que, na prática, se afigurava com o mesmo (ou similar) teor da ação cautelar.

Diante disso, em 1994 adveio a reforma do CPC/73 que atingiu diretamente o tema das tutelas provisórias, reescrevendo o texto legal para criar uma tutela provisória satisfativa "genérica", permanecendo o procedimento cautelar nos moldes do art. 804.

Ocorre que, ressalvados os devidos elogios a esta mudança, tal alteração significou uma transformação na forma como se deveria proceder a análise dos requisitos autorizadores para concessão da tutela pretendida, o que gerou uma verdadeira "confusão" entre os senhores advogados e juízes.

Explica-se: o advogado que estava "acostumado" a requerer aquela "tutela cautelar satisfativa" teria como dever, neste momento, utilizar-se da "tutela provisória satisfativa", a qual possuía requisito muito similares, ocasionando, assim, muitas das vezes, confusão entre elas, o que acabava 
ensejando o indeferimento, ou até, o não conhecimento da medida (requisitos de admissibilidade).

Assim, somente após passados 8 (oito) anos, em 2002, o CPC/73 foi objeto de nova reforma, com a inclusão do $§ 7^{\circ}$ ao art. 273, estabelecendo, assim, o instituto da fungibilidade entre as medidas cautelares e provisórias, de modo a atenuar os equívocos processuais cometidos e assegurar a tutela jurisdicional pretendida.

Tal sistema se perdurou até a entrada em vigor do Código de Processo Civil de 2015, o qual houve por bem unificar o regramento das tutelas provisórias (gênero), reorganizando topologicamente as disposições legais do código e inserindo-as a partir do Livro V - DA TUTELA PROVISÓRIA, louvável decisão, diga-se de passagem.

\section{Capítulo 2. CONCEITOS}

\subsection{Conceito da Tutela Provisória}

Conforme definido pelo professor Alexandre Freitas Câmara ${ }^{1}$, as “Tutelas Provisórias são tutelas jurisdicionais não definitivas, fundadas em cognição sumária (isto é fundadas em um exame menos profundo da causa, capaz de levar à prolação de decisões baseadas em juízo de probabilidade e não de certeza)." Asseverando, ainda, que elas podem "fundar-se em urgência ou em evidência (daí por que se falar em tutela de urgência e em Tutela da evidência)".

${ }^{1}$ CÂMARA. Alexandre Freitas. O Novo Processo Civil Brasileiro. 1a ed. Atlas. São Paulo.2015. P. 157. 
Antes de adentar às especificações, classificações e fundamentos das tutelas provisórias, vale estabelecer alguns conceitos para melhor análise e compreensão do presente trabalho monográfico.

Pois bem, como consignado acima, as tutelas provisórias fazem parte das tutelas jurisdicionais oferecidas pelo Estado, a quais são classificadas entre provisórias e definitivas. Daí a razão da definição por exclusão ("tutelas jurisdicionais não definitivas").

Diante disso, tem-se correto afirmar que a tutela provisória, além de ser espécie das tutelas jurisdicionais, ela também é gênero das tutelas de urgência e evidência, que foi acertadamente unificado pelo CPC/2015, dispostas a partir do art. 294

\subsection{Conceito da Tutela Definitiva}

Apesar do presente trabalho monográfico se focar na análise da tutela provisória, é imprescindível estabelecer e firmar os conceitos referentes às tutelas definitivas.

Neste passo, Fredie Didier² defende que a Tutela definitiva é "aquela obtida com base em cognição exauriente, com profundo debate acerca do objeto da decisão, garantindo-se o devido processo legal, o contraditório e a ampla defesa.".

\footnotetext{
${ }^{2}$ DIDIER JR. Fredie. Curso de Direito Processual Civil. 10a ed. Editora Juspodim. Salvador. 2015. P. 562
} 
Mas não é só, com leciona em sua obra a respeito do Código de Processo Civil de 2015 (“CPC/2015”), a tutela definitiva é aquela que está apta a atingir à estabilidade da coisa julgada, ou seja, que pode ser "coberta" pela segurança jurídica, tornando-se imutável ao longo do tempo, asseverando, por fim, que toda e qualquer tutela definitiva poderá ser requerida na modalidade provisória.

Isto é, não há uma diferença ontológica entre as tutelas provisórias e definitivas, o que se tem é uma distinção em razão da possível consequência jurídica a gerada.

Noutras palavras, a diferenciação está no fato da aptidão para gerar coisa julgada ou não, sendo certo que a tutela provisória, diferentemente da tutela definitiva, não possui essa aptidão.

Além disso, como leciona Didier, a tutela definitiva também poderá ser satisfativa ou cautelar.

Neste cenário, a tutela definitiva satisfativa seria aquela que visa "certificar elou efetivar o direito material. Predispõe-se à satisfação de um direito material com a entrega do bem da vida almejado." ${ }^{3}$

Sucede, porém, há situações em que o bem da vida almejado necessita ser acautelado de imediato, não podendo aguardar o término da análise exauriente do judiciário para que se efetive o direito material.

\footnotetext{
${ }^{3}$ DIDIER JR. Fredie. Curso de Direito Processual Civil. 10a ed. Editora Juspodim. Salvador. 2015. P. 562
} 
Diante disso, criou-se a tutela definitiva cautelar, a qual, também nas palavras de Didier4 “não visa à satisfação de um direito (ressalvado, obviamente o próprio direito à cautela), mas, sim, a assegurar a sua futura satisfação, protegendo-o".

Tais aspectos gerais a respeito da tutela definitiva são importantes para a compreensão do "microssistema" das tutelas provisórias, uma vez que esta, como se verá ao longo do presente trabalho monográfico, também se subdivide em tutela provisória satisfativa ou cautelar, exatamente como acontece com as tutelas definitivas.

\subsection{Conceitos de Provisório / Referido / Temporário}

Outra importante diferenciação que se deve fazer antes do estudo aprofundado a respeito das tutelas provisórias (latu sensu), é a que toca os conceitos de provisoriedade; referibilidade e temporariedade/transitividade.

Como visto acima, as tutelas jurisdicionais se subdividem em 2 (duas): (i) definitivas e (ii) provisórias, o que se dá pelo grau de cognição exercido pelo juiz, e essas, por sua vez, também se subdividem;

(i) Tutelas Definitivas

$>$ Satisfativa: certifica ou efetiva um direito material

\footnotetext{
${ }^{4}$ DIDIER JR. Fredie. Curso de Direito Processual Civil. 10a ed. Editora Juspodim. Salvador. 2015.
} P.562 
Cautelar: cria condições para que o agente possa efetivar o direito material em momento oportuno.

(ii) Tutelas Provisórias

$>$ Satisfativa: certifica ou efetiva um direito material, ainda que em cognição sumária, que poderá ser confirmada ou revogada;

$>$ Cautelar: cria condições para que o agente possa efetivar o direito material em momento oportuno.

Até este ponto, aparentemente, nenhuma dúvida. $\mathrm{O}$ ponto interessante, ainda conceitual, está na terminologia "temporário" que incorre nas tutelas definitivas cautelares, ou como o il. Professor Fredie menciona, no seu grau de "referibilidade". 5

Explica-se: elucida o referido doutrinador que a tutela cautelar se difere da satisfativa não só pelo fato de possuírem objetos distintos, mas também porque "a tutela cautelar tem duas características peculiares: a referibilidade e a temporariedade".

Em análise, a tutela cautelar, como visto, tem por escopo preservar o direito material, definido como o "direito acautelado". Assim, afirma-se que a tutela cautelar é um instituto que se refere a outro direito, daí o termo "referibilidade" que não o que deve ser apreciado pelo magistrado quando da sua concessão.

\footnotetext{
${ }^{5}$ DIDIER JR. Fredie. Curso de Direito Processual Civil. 10a ed. Editora Juspodim. Salvador. 2015. P. 562.
} 
Isto é, quando o magistrado analisa o pedido de tutela cautelar, este tem o condão de analisar se estão presentes 2 (dois) requisitos: (i) perigo (ii) probabilidade do direito, conforme art. 294 do CPC/2015.

No entanto, tratando-se do $2^{\circ}$ requisito (probabilidade do direito), o magistrado apenas verifica/analisa o direito à cautela e não o direito acautelado, que é, justamente, o direito que recai a tutela cautelar.

Ou seja, neste primeiro contato, o que o magistrado analisa é a referibilidade do direito a cautela do direito acautelado.

E mais, cabe mencionar que o aspecto temporário inerente à tutela cautelar, tendo em vista que sua eficácia está limitada no tempo, tal definição é extraída dos ensinamentos do il. Professor Daniel Mitidiero ${ }^{6}$.

Assim, seja ela definitiva ou provisória, a tutela cautelar sempre será temporária, sendo eficaz até o fim da preservação que se propõe. O que não pode se admitir é a caracterização de uma tutela definitiva provisória, pois seria uma contradição da própria conceituação.

\footnotetext{
${ }^{6}$ MITIDIERO. Daniel. Tendência em material de tutela sumária: da tutela cautelar à técnica antecipatória. Revista de Processo. São Paulo: RT, 2011, n. 197, p. 35.
} 


\section{Capítulo 3. ASPECTOS GERAIS DA TUTELA PROVISÓRIA}

\subsection{Características}

Conforme leciona Fredie, a tutela provisória é marcada por 3 (três) características essenciais:

(i) sumariedade da cognição, tendo em vista que a análise é feita de maneira superficial sobre o objeto em discussão, sendo autorizado ao juiz proferir decisão fundada em um juízo de probabilidade;

(ii) precariedade, uma vez que, a rigor, a tutela provisória conservará sua eficácia até ulterior decisão judicial em sentido contrário, podendo ser modificada, revogada a qualquer tempo, como prevê o art. 296, caput, do CPC/20157\%

Obs. Neste particular, no que tange à revogação ou modificação da tutela provisória anteriormente concedida, como sustenta $\mathbf{Z a v a s c k i}^{8}$, tal circunstancia somente poderá ocorrer "em razão de uma alteração do estado de fato ou de direito ou do estado de prova - quando, por exemplo, na fase de instrução, restarem evidenciados fatos que não correspondam àqueles que autorizaram a concessão da tutela”.

\footnotetext{
${ }^{7}$ A tutela provisoria conserva sua eficácia na pendêcia do processo, mas pode, a qualquer tempo, ser revogada ou modificada.

${ }^{8}$ ZAVASCKI.Teori Albino. Antecipação de Tutela, 2a ed., cit, o. 35-36.
} 
(iii) Inapta a formar "coisa julgada", haja vista ter sido fundada em cognição sumária e precária.

\subsection{Espécies}

A tutela provisória, como visto acima, poderá ser concedida de forma antecipada (satisfativa) ou cautelar.

Tratando-se da tutela antecipada (satisfativa), significa dizer que é autorizado pelo ordenamento jurídico brasileiro a antecipação provisoriamente da satisfação do direito propriamente dito, aquilo que é objeto da ação.

Já no que tange à tutela cautelar, esta reflete à uma tutela jurisdicional que visa assegurar o direito afirmado, não se confunde com o mérito da causa, simplesmente busca a cautela do direito litigioso ou do próprio processo.

Didier" afirma que a tutela provisória cautelar "tem, assim, dupla função: é a provisória por dar eficácia imediata à tutela definitiva não-satisfativa; e é cautelar em que resguarda o direito a ser satisfeito, acautelando-o."

\subsection{Regime Jurídico (CPC/2015, art. 294)}

A tutela provisória pode apresentar-se de 2 (duas) formas, urgência e evidência.

${ }^{9}$ DIDIER JR. Fredie. Curso de Direito Processual Civil. 10a ed. Editora Juspodim. Salvador. 2015. P. 569 
As tutelas de urgência, como definido pelo art. 300 do CPC/2015, sejam elas satisfativas (antecedentes) ou cautelares, pressupõem a verificação da "probabilidade do direito" e do "perigo de dano ou o risco ao resultado útil do processo".

Já as tutelas de evidência não se fundam na demonstração do perigo de dano, elas são absolutamente desprovidas de "urgência".

Por outro lado, a concessão da tutela de evidência ficará condicionada à demonstração cabal (quase $80 \%$ - estimativa da experiência forense) da probabilidade do direito discutido na causa.

Noutras palavras, em se tratando de tutela de evidência, apesar do legislador não ter exigido a demonstração do requisito da urgência, fez questão de reduzir as hipóteses de sua incidência para aquelas em que é "quase certa" a procedência do pedido autoral, o que, inclusive, explica o motivo da escolha do nome desse novo instituto: "evidência".

Tal previsão está disposta no art. 311 do CPC/2015, que assim aduz:

"Art. 311. A tutela da evidência será concedida, independentemente da demonstração de perigo de dano ou de risco ao resultado útil ao processo, quando:

I - ficar caracterizado o abuso do direito de defesa ou o manifesto propósito protelatório da parte; 
II - as alegações de fato puderem ser comprovadas apenas documentalmente e houver tese firmada em julgamento de casos repetitivos ou súmula vinculante;

III - se tratar de pedido reipersecutório fundado em prova documental adequada do contrato de depósito, caso em que será decretada a ordem de entrega do objeto custodiado, sob cominação de multa;

IV - a petição inicial for instruída com prova documental suficiente dos fatos constitutivos do direito do autor, a que o ré não oponha prova capaz de gerar dúvida razoável.

Parágrafo único. Nas hipóteses dos incisos II e III, o juiz poderá decidir liminarmente."

Ressalta-se, por fim, que no parágrafo único deste dispositivo infraconstitucional, o legislador adotou previsão de concessão de medida inaldita altera parte.

\subsection{Incidental e Antecedente}

Seguindo a ordem do il. Professor Fredie Didier ${ }^{10}$, ao menos neste momento conceitual e procedimental da Tutela Provisória, deve-se destacar as suas duas formas de concessão, quais sejam: (i) incidental ou (ii) antecedente.

\footnotetext{
${ }^{10}$ DIDIER JR. Fredie. Curso de Direito Processual Civil. 10a ed. Editora Juspodim. Salvador. 2015. P. 570 .
} 
Como prevê o art. 294, § único, do $\mathrm{CPC} / 2015$, “A tutela provisória de urgência, cautelar ou antecipada, pode ser concedida em caráter antecedente ou incidental."

Isto significa dizer que a conduta do juiz pode ser definida pelo momento que em que é concedida a referida tutela provisória, independente da sua classificação, seja ela de urgência, cautelar ou antecipada (satisfativa).

Em comparação, a medida incidental é "aquela requerida dentro do processo em que se pede ou já se pediu a tutela definitiva, no intuito de adiantar seus efeitos (satisfação ou acautelamento), independente do pagamento de custas (art. 295, CPC) ${ }^{\prime 11}$.

Já a medida antecedente é "aquela que deflagra o processo em que se pretende, no futuro, pedir a tutela definitiva. É requerimento anterior à formulação do pedido de tutela definitiva e tem por objetivo adiantar seus efeitos (satisfação ou acautelamento). Primeiro, pede-se a tutela provisória; só depois, pede-se a tutela definitiva." 12

Neste contexto, como será melhor exemplificado a seguir no presente trabalho monográfico, somente a tutela provisória fundada na urgência pode ser requerida em caráter "antecedente". Até porque, esta novidade trazida com o Código de Processo Civil de 2015 se fez necessária para atender a casos em que a urgência já algo iminente no momento da propositura da ação, de modo que a parte não dispõe de tempo hábil necessário para aprimorar a sua petição inicial,

\footnotetext{
${ }^{11}$ DIDIER JR. Fredie. Curso de Direito Processual Civil. 10a ed. Editora Juspodim. Salvador. 2015. P. 571.

${ }^{12}$ DIDIER JR. Fredie. Curso de Direito Processual Civil. 10a ed. Editora Juspodim. Salvador. 2015. P. 571.
} 
muito menos anexar todos os documentos que fazem parte e que seriam pertinentes para a causa.

Como exemplo evidente, pode-se indicar o caso de necessidade de realização de cirurgia vital para a sobrevivência da parte e há uma negativa da seguradora. Neste momento, afigura-se extremamente cabível o manejo da tutela provisória de urgência em caráter antecedente, pleiteando, apenas, a "liminar" para a realização da cirurgia em comento, para, somente após, ingressar com a "demanda principal", ou seja, complementar as argumentações e documentos já apresentados no processo.

\subsection{Cabimento}

A tutela provisória é cabível em todos os procedimentos comuns, assim como nos juizados especiais cíveis ${ }^{13}$.

Diverge desse posicionamento o il. Professor Athos Gusmão Carneiro, na medida em que defende que não haveria cabimento no caso dos juizados especiais, sejam seles estaduais ou federais, tendo em vista a "principiologia que informa este procedimento". No entanto, conclui que, na prática forense, não é isso que é observado. ${ }^{14}$

Didier também ressalta a possibilidade e adequação de utilização da tutela provisória nos procedimentos especiais (art. 318, parágrafo único, CPC/2015).

\footnotetext{
${ }^{13}$ DIDIER JR. Fredie. Curso de Direito Processual Civil. 10a ed. Editora Juspodim. Salvador. 2015. P. 575

${ }^{14}$ CARNEIRO. Athos Gustão. Da Antecipação de tutela. 5a ed., cit., p. 112.
} 
Assim observa: "a tutela provisória conta com previsão específica em alguns procedimentos especiais. Isso, em geral, com base na constatação de que o direito tutelado pode ser evidenciado de plano ou merece um tratamento diferenciado por sua relevância social. Para a concessão de tutela provisória nesses procedimentos especiais, a lei exige o preenchimento de outros pressupostos, distintos daqueles previstos nos arts. 303, 305 e 311, CPC, como acontece nas ações possessórias (art. 562 do CPC) e nas ações de despejo (art. 59, $1^{\circ}$, Lei n. 8.254/1991)”.

\subsection{Na Sentença e em Grau Recursal}

A tutela provisória também poderá ser concedida na sentença, ou, até mesmo, em grau de recurso.

Tratando-se de sentença, esta é a maneira mais célere de atribuir eficácia imediata à decisão judicial, na medida em que, se concedida tutela provisória ao tempo da sentença, eventual recurso de apelação interposto em face desta sentença não disporá de efeito suspensivo automático, regra que se extrai do art. 1.012, parágrafo primeiro, inciso V. Confira-se:

"Art. 1.012. A apelação terá efeito suspensivo.

$\S 1^{\circ}$ Além de outras hipóteses previstas em lei, começa a produzir efeitos imediatamente após a sua publicação a sentença que:

(...)

$V$ - confirma, concede ou revoga tutela provisória; 
Afigura-se uma técnica de adiantamento provisório dos efeitos da tutela e, não, da tutela em $\mathrm{si}^{15}$, sendo certo que a regra do sistema recursal brasileiro é de que o recurso manejado contra a sentença disponha de efeito suspensivo, justamente, visando a garantia dos direitos e a segurança jurídica, prezando pelo duplo grau de jurisdição, todos os pilares que formam o direito processual civil constitucional.

Há também a possibilidade da tutela provisória ser requerida em sede recursal.

Isto é, estando preenchidos os requisitos para tanto (probabilidade do direito e perigo de dano ou de risco ao resultado útil ao processo), poderá a parte requerer de forma incidental no seu próprio recurso, dirigindo ao tribunal, pedido para que seja concedida a tutela provisória recursal pleiteada.

Tal regra se verifica da leitura do parágrafo único do art. 299, do CPC/2015, o qual aduz que "a tutela provisória será requerida ao órgão jurisdicional competente para apreciar o mérito".

Neste caso, em hipótese de deferimento da medida liminar (tutela provisória), tal decisão afetará de imediato a eficácia da sentença recorrida, obstando, assim, o seu cumprimento.

Com efeito, abre-se parênteses para chamar a atenção para um aspecto prático, o qual foi devidamente atendido pelo legislador em mais uma atitude louvável.

\footnotetext{
${ }^{15}$ DIDIER JR. Fredie. Curso de Direito Processual Civil. 10a ed. Editora Juspodim. Salvador. 2015. P.
} 581. 
Isto é, na prática forense, em alguns casos, apesar de requerida tutela provisória no recurso de apelação (incidental) em face da sentença, tal pedido somente é apreciado muito tempo após, em razão da morosidade dos procedimentos cartorários e processamento das petições, para posterior remessa ao Tribunal Estadual.

Assim, para o fim de evitar prejuízo para qualquer das partes, o CPC/2015 trouxe, em seu dispositivo 995 e 1.1012, $\S 4^{\circ}$, uma regra procedimental que preenche essa lacuna e tem por objeto atender a esses casos práticos.

Tais artigos trazem a possibilidade de se formular apenas o pedido de tutela provisória diretamente ao Tribunal (órgão competente para apreciar tal pedido após a prolação da sentença), mesmo antes do competente Recurso de Apelação ser distribuído.

E isto pode ser realizado de duas formas:

(i) requerimento ao tribunal, quando se estiver entre o período da interposição do recurso e sua distribuição em $2^{\mathrm{a}}$ instância e;

(ii) requerimento ao relator, quando o recurso já tiver sido distribuído

Com isso, o legislador andou bem e garantiu a segurança jurídica, evitando prejuízos para a parte. 


\subsection{Precariedade}

Ainda no estudo dos aspectos gerais da Tutela provisória (gênero), guiando-se pela honrosa doutrina contemporânea de Fredie Didier, importante ressaltar que tal instituto jurídico goza de precariedade.

Isto é, tem-se correto afirmar que a Tutela provisória, seja ela de urgência ou evidência, poderá ser revogada a qualquer tempo e em qualquer grau de jurisdição, desde que haja provocação da parte e que se faça por decisão fundamentada do juiz (CPC/2015, art. 296 e 298).

Neste contexto, Marinoni ${ }^{16}$ leciona que tal revogação somente é permitida caso tenha sido alterado o quadro fático até então estabelecido. Ou seja, a tutela provisória outrora concedida somente poderá ser revogada caso o fator que ensejou a concessão da medida provisória venha não mais exista, alterando-se as circunstâncias do caso.

Um aspecto interessante a respeito da revogação é o seu efeito ex tunc concedido pelo art. 520, II, do CPC/2015, devendo a parte restabelecer o status quo ante.

\subsection{Do Recurso Cabível}

Em face da decisão que concede, revoga ou modifica a tutela provisória caberá o Recurso de Agravo de Instrumento por 2 (dois) motivos: (i) trata-se de decisão interlocutória e (ii) tal hipótese foi contemplada pelo rol taxativo previsto no art. 1.015 do CPC/2015.

\footnotetext{
${ }^{16}$ MARINONI, Luiz Guilherme. Antecipção de tutela, 8a ed., 2004, p. 194.
} 
Ressalta-se, porém, que se a tutela provisória for concedida/revogada/modificada de forma incidental na sentença, o recurso cabível não mais será o Agravo de Instrumento, e sim o Recurso de Apelação, devendo-se, ainda, registrar que tal parte do recurso que atacar a tutela provisória concedida não disporá de efeito suspensivo.

Tal regramento está disposto no art. 1.012, parágrafo primeiro do $\mathrm{CPC} / 2015$.

Por fim, caso a tutela provisória seja concedida/revogada/modificada em sede recursal, dependendo da circunstância em que for efetivado tal ato, poderá ser atacada pelos seguintes meios:

(i) Agravo interno, em caso de tutela provisória ser concedida através de decisão monocrática do relator (CPC/2015, art. 1021);

(ii) Recurso Especial, na hipótese de tutela provisória ser concedida pelo colegiado (turma julgadora), oportunidade em que é autorizado a interposição Recurso especial pra o fim de verificar o preenchimento dos requisitos legais para a concessão. 


\subsection{Da Eficácia da Decisão}

Como já existia no CPC/1973, o Juiz dispõe de meios coercitivos para a efetivação da sua decisão, meios idôneos e que se afigurem necessários para cumprimento da determinação judicial.

E tratando-se, especificamente, da tutela provisória, não podia ser diferente.

Neste passo, importante a transcrição do art. 297 do CPC/2015:

“Art. 297. O juiz poderá determinar as medidas que considerar adequadas para efetivação da tutela provisória.

Parágrafo único. A efetivação da tutela provisória observará as normas referente ao cumprimento provisório da sentença, no que couber"

É chamado pelo ordenamento jurídico brasileiro ${ }^{17}$ de "poder geral de cautela", de modo que o Juiz poderá adotar outras medidas coercitivas, ainda que não solicitadas pela parte, para o fim de dar efetividade a sua decisão, caso a outra parte não a cumpra como determinado.

Como referência, cabe destacar o enunciado 31 do Fórum Permanente de Processualistas Civis ("FPPC") que assim versa "O poder geral de cautela está mantido no NCPC".

\footnotetext{
${ }^{17}$ DIDIER JR. Fredie. Curso de Direito Processual Civil. 10a ed. Editora Juspodim. Salvador. 2015.
} P. 590. 


\section{Capítulo 4. DA TUTELA DE URGÊNCIA}

\subsection{Regramento}

Como brevemente ilustrado acima neste trabalho monográfico, a tutela provisória de urgência é regida pelo art. 300 e seguintes do CPC/2015, e pressupõe a demonstração, pela parte, a demonstração de 2 (dois) requisitos,

quais sejam: (i) probabilidade do direito e (ii) perigo de dano ou risco ao resultado útil do processo.

Em estudo específico a respeito desta medida, pode-se observar que o magistrado poderá concedê-la liminarmente (inaudita altera parte), sem a oitiva do Réu, ou, ainda, após a prévia justificação deste.

Tal regra se extrai do parágrafo segundo do aludido dispositivo infraconstitucional.

Em continuidade, cabe registrar que, como determina o parágrafo terceiro, a tutela de urgência não será concedida quando houver perigo in reverso.

Noutras palavras, com essa disposição o legislador pretendeu resguardar eventual prejuízo a ser ocasionado caso o magistrado entenda por conceder a tutela provisória antes mesmo de analisar profundamente (cognição exauriente) o tema. 
Assim, se a tutela puder ocasionar dano ou perigo de irreversibilidade dos efeitos da decisão, esta não poderá ser concedida.

Neste mesmo sentido, aduz o art. 302 do CPC/2015 que "independentemente da reparação por dano processual, a parte responde pelo prejuízo que a efetivação da tutela de urgência casar à parte adversa”.

Deve-se reparar que o legislador está bastante preocupado com a concessão desse tipo de tutela.

Isto é, em razão da análise sumária acerca da matéria, restringindo o magistrado à verificação de preenchimento dos requisitos obrigatórios (probabilidade do direito + perigo de dano ou resultado útil), o legislador criou mais um regramento para prevenir o direito da parte, indicando providências a serem adotadas caso a medida liminar venha a prejudicar outra parte.

\subsection{Do Procedimento}

Também como já abordado de forma objetiva no início do presente trabalho monográfico, a tutela de urgência poderá ser requerida de forma (i) incidental, (ii) antecedente, ou (iii) cautelar.

\subsubsection{Incidental}

Tratando-se da modalidade incidental, não há grandes novidades trazidas pelo CPC/2015, de modo que o pedido de tutela provisória de urgência poderá ser requerido no curso do processo, a qualquer momento, desde que preenchidos os seus requisitos autorizadores. 


\subsubsection{Antecedente}

Tal panorama se altera quando se estuda a tutela de urgência requerida em caráter antecedente.

Como prevê o art. 303 do diploma processual vigente, "nos casos em que a urgência for contemporânea a propositura da ação, a petição inicial pode limitar-se ao requerimento da tutela antecipada e à indicação do pedido de tutela final, com a exposição a lide, do direito que se busca realizar e do perigo de dano ou do risco ao resultado útil do processo."

Tal disposição é novidade no ordenamento jurídico brasileiro, de modo que autoriza a parte elaborar uma petição inicial "incompleta", contendo, basicamente, o seu pedido liminar e a "indicação" do seu pedido final.

Neste particular, abre-se um parêntese no estudo do regramento legal, para identificar a intenção do legislador.

Isto é, perceba-se que o dispositivo infraconstitucional, tal como está redigido, soluciona problemas práticos que os advogados sempre tiveram que enfrentar na "vida forense".

Com efeito, quem atua na advocacia contenciosa cível sabe que não são poucas as situações em que a parte necessita de imediata tutela jurisdicional, no entanto, naquele momento de urgência, não se dispõe de todo o conteúdo probatório robusto para o manejo de uma ação, o que, até então, obstava a 
distribuição do petitório inicial e, via de consequência, a parte acabava desamparada.

Entretanto, com a aplicação da regra prevista no art. 303 do CPC2015, a parte poderá, ainda que não disponha de todos os documentos necessários para o pleito inicial, distribuir demanda requerendo a tutela provisória de urgência antecipada em caráter antecedente.

Mais uma vez, louvável foi a decisão legislativa com a inclusão deste dispositivo infraconstitucional, afigurando-se um marco na prática forense.

Retornando-se ao procedimento propriamente dito da tutela antecipada de urgência requerida em caráter antecedente, deve-se indicar as disposições do art. 303 do diploma processual. Veja-se:

"Art. 303. Nos casos em que a urgência for contemporânea à propositura da ação, a petição inicial pode limitar-se ao requerimento da tutela antecipada e à indicação do pedido de tutela final, com a exposição da lide, do direito que se busca realizar e do perigo de dano ou do risco ao resultado útil do processo.

$\S 1^{o}$ Concedida a tutela antecipada a que se refere o caput deste artigo:

I - o autor deverá aditar a petição inicial, com a complementação de sua argumentação, a juntada de novos documentos e a confirmação do pedido de tutela final, em 15 (quinze) dias ou em outro prazo maior que o juiz fixar;

II - o réu será citado e intimado para a audiência de conciliação ou de mediação na forma do art. 334;

III - não havendo autocomposição, o prazo para contestação será contado na forma do art. 335.

$\S 2^{\circ}$ Não realizado o aditamento a que se refere o inciso I do $\S$ $I^{\circ}$ deste artigo, o processo será extinto sem resolução do mérito. 
$\S 3^{o} O$ aditamento a que se refere o inciso I do $\S 1^{\circ}$ deste artigo darse-á nos mesmos autos, sem incidência de novas custas processuais.

$\S 4^{\circ} \mathrm{Na}$ petição inicial a que se refere o caput deste artigo, o autor terá de indicar o valor da causa, que deve levar em consideração o pedido de tutela final.

§ 5O $O$ autor indicará na petição inicial, ainda, que pretende valerse do beneficio previsto no caput deste artigo.

§ $6^{0}$ Caso entenda que não há elementos para a concessão de tutela antecipada, o órgão jurisdicional determinará a emenda da petição inicial em até 5 (cinco) dias, sob pena de ser indeferida e de o processo ser extinto sem resolução de mérito."

Como prevê o aludido dispositivo, não concedida a tutela provisória pretendida, o magistrado concederá à parte o prazo adicional de 5 (cinco) dias para emendar a petição inicial, restando autorizada a complementação na argumentação e juntada de novos documentos.

Uma vez concedida a medida, tendo em vista que a petição inicial se encontra "incompleta", deverá o autor também aditar a exordial com a “complementação de sua argumentação" e a "juntada de novos documentos e a confirmação da tutela final", sendo certo que tal providência deverá ser realizada até $\underline{15}$ (quinze) dias contados da publicação da decisão liminar ou outro prazo que o juiz fixar (inciso I) sob pena de extinção sem resolução de mérito $\left(\S 2^{\circ}\right)$.

Neste mesmo momento, o réu deverá ser (A) intimado da decisão que concedeu a tutela provisória para que possa dar cumprimento e (B) citado para comparecer em audiência de conciliação ou de mediação, oportunidade em que, caso não concretizada qualquer Autocomposição entre as partes, inicia-se o prazo para réu apresentar contestação. 


\subsubsection{Das Inconsistências Procedimentais (Crítica ao Sistema)}

Com efeito, como bem ilustra o professor Didier "18, "é necessário que se observe, contudo, que o prazo de resposta do réu não poderá começar a ser contado antes da sua ciência inequívoca do aditamento da petição inicial do autor, para que se garanta a ele, réu, o lapso temporal mínimo de quinze dias para resposta à demanda do autor em sua inteireza."

Entretanto, em que pese o entendimento esposado pelo doutrinador, o que se faz com todas as vênias pertinentes, não é isso que se verifica do texto legal, na medida em que o legislador, apesar da louvável criação do instituto, deixou de harmonizar os prazos previstos.

A título de exemplo para demonstrar a verdadeira incoerência dos prazos estipulados no procedimento, como também aventa o referido doutrinador ${ }^{19}$, caso o objeto da lide não seja admissível a Autocomposição, o réu será citado para contestar a demanda.

No entanto, tal prazo somente deveria iniciar-se quando da intimação a respeito do aditamento da petição inicial realizado pelo autor. Entretanto, como se verifica do texto infraconstitucional, não é isso que ocorre, causando certa inseguranca jurídica para este novo sistema.

\footnotetext{
${ }^{18}$ DIDIER JR. Fredie. Curso de Direito Processual Civil. 10a ed. Editora Juspodim. Salvador. 2015. P. 603/604

${ }^{19}$ DIDIER JR. Fredie. Curso de Direito Processual Civil. 10a ed. Editora Juspodim. Salvador. 2015. P. 604
} 
Em interpretação do procedimento legal previsto, tem-se o seguinte panorama na prática:

\section{$\underline{1^{\circ} \text { passo: }}$}

Pedido de tutela provisória de urgência em caráter antecedente formulado pela parte ao juízo competente para julgar a tutela definitiva.

20 passo:

Verificação pelo Juiz a respeito da presença dos requisitos da tutela provisória

$\underline{3^{\circ} \text { passo: }}$

Havendo preenchimento dos requisitos, concessão da medida liminar

\section{- Consequências concomitantes:}

(i) Prazo de 15 (quinze) dias para o Autor complementar sua petição inicial;

Obs. Caso o Autor não cumpra esta determinação, o processo será extinto, sem resolução de mérito, consoante a regra disposta no art. 303, parágrafo segundo, do CPC/2015

(ii) Intimação do Réu para cumprir a decisão liminar e/ou apresentar "Recurso".

Obs. Neste particular, como visto acima, o recurso cabível em face da decisão que concede/revoga/modifica a tutela provisória é o Agravo de 
instrumento, tratando-se de $1^{\text {a }}$ instância (não sendo concedida na

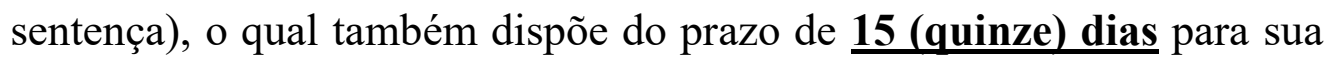
interposição.

Obs. Caso não haja interposição de recurso, a tutela liminar antecedente concedida se tornará estável, instituto este que será também abordado a seguir no presente trabalho monográfico.

(iii) Citação do Réu para comparecimento em audiência ou, caso a lide não seja passível de Autocomposição, prazo de 15 (quinze) dias para apresentação da contestação, o que somente se iniciará após a juntada do mandado positivo nos autos (CPC/2015, art. 231, II).

Assim, em análise detida do procedimento criado pelo legislador, verifica-se que, em determinadas situações, em razão da concomitância na fluência dos prazos processuais, haverá confusão quanto ao destino do processo.

\section{Estudo de casos:}

\section{$\underline{1^{\mathrm{a}} \text { hipótese }}$}

Imagina-se que houve a concessão da tutela liminar antecedente, iniciando-se, assim, os prazos acima elencados.

No entanto, como o prazo para aditamento da petição inicial pelo Autor (15 dias) e o prazo para o Réu apresentar Recurso (15 dias) iniciam-se no mesmo momento (considerando que tenha sido intimado no dia da decisão). 


\section{Como deverá agir o magistrado?}

\section{O processo será extinto ou ter a tutela estabilizada?}

Caso o Autor não adite a sua inicial, a regra processual prevê que o processo deverá ser extinto, porém, convém destacar que a mesma regra processual prevê que se o Réu não interpuser recurso da decisão que conceder a tutela provisória antecedente, a tutela deverá ser estabilizada e o processo arquivado.

Sucede, porém, se o procedimento prevê que tais prazos têm início contados da decisão liminar e ambos possuem o prazo de 15 (quinze) dias, como definir se o processo deverá seguir para a estabilização ou extinção?

\section{$\underline{2^{\mathrm{a}} \text { hipótese }}$}

Em outro caso, havendo a concessão da tutela provisória de urgência em caráter antecedente, e considerando que houve o devido aditamento, pelo Autor, de sua petição inicial.

Trabalhando a hipótese de o Réu não apresentar Recurso em face da alusiva decisão, como prevê o art. 304, parágrafo primeiro, do CPC/2015, a tutela será estabilizada e o processo será extinto.

Porém, deve-se atentar para o fato de que, no mesmo momento em que o réu é intimado para apresentar recurso em face da decisão liminar, este também é citado para comparecer em audiência ou não sendo possível, apresentar contestação à demanda. 
Entretanto, considerando a consequência automática prevista pelo procedimento, para que o Réu possa ter o direito de apresentar defesa às alegacões iniciais, ele, necessariamente, deverá apresentar Recurso em face da decisão liminar, uma vez que, caso não o faça, a tutela se tornará estável, e o processo será extinto, suprimindo, assim, o direito processual-constitucional de defesa do Réu.

\section{Estar-se-ia diante de hipótese de recurso obrigatório?}

Realmente tais problemáticas procedimentais deverão ser enfrentadas pelos Tribunais pátrios, de modo a dar maior segurança jurídica aos jurisdicionados.

\subsubsection{Estabilização $\times$ Coisa Julgada}

Como define o art. 304 do CPC/2015, torna-se estável se da decisão que conceder não for interposto o respectivo recurso.

Cumpre ressaltar que o texto legal faz alusão a um novo instituto, qual seja: a estabilidade, até então, inexistente no ordenamento jurídico pátrio, o qual merece um estudo mais aprofundado.

Ensina Didier ${ }^{20}$ que os objetivos da estabilização da decisão são: “i) afastar o perigo da demora com a tutela de urgência; e ii) oferecer resultados efetivos e imediatos diante da inércia do réu."

\footnotetext{
${ }^{20}$ DIDIER JR. Fredie. Curso de Direito Processual Civil. 10a ed. Editora Juspodim. Salvador. 2015. P. 606
} 
No entanto, tal instituto não pode ser confundido com a coisa julgada.

Neste contexto, Alexandre Câmara ${ }^{21}$ comenta que "a decisão concessiva da tutela de urgência estável não faz coisa julgada (isto é, não se torna imutável e indiscutível, como estabelece o Art. 304, $\$ 6^{\circ}$, o que é consequência inexorável do fato de ter sido ela proferida com apoio em cognição sumária e não em cognição exauriente (sendo esta essencial para que a decisão judicial alcance a autoridade de coisa julgada)."

Assim, percebe-se, já de antemão, que a estabilidade, apesar de possuir grau de segurança e eficácia duradoura, não pode ser equiparada ao instituto da coisa julgada, o qual goza de determinados requisitos e pressupostos mais profundos, assumindo caráter imutável.

Neste particular, observados os ensinamentos dos doutrinadores contemporâneos, afirma-se que a estabilidade nunca assumirá viés de coisa julgada, pois não enfrenta o contraditório de maneira plena, pressuposto básico para a imutabilidade da decisão.

Diante disso, em que pese a estabilidade produzir efeitos de forma perene, poderá ser posteriormente impugnada, através de ação autônoma, conforme prevê o art. $304, \S 2^{\circ}$, do $\mathrm{CPC} / 2015$, razão pela qual não pode ser confundida com coisa julgada.

\footnotetext{
${ }^{21}$ CÂMARA. Alexandre Freitas. O Novo Processo Civil Brasileiro. 1a ed. Atlas. São Paulo.2015. P.163
} 


\subsubsection{Cautelar em Caráter Antecedente}

Esta modalidade se assemelha muito com o instituto já existente no CPC/73, sendo hipótese de tutela requerida pelo jurisdicionado com vistas a segurar o seu direito (direito acautelado).

Como pontua Didier ${ }^{22}$, o seu objetivo é "i) adiantar provisoriamente a eficácia da tutela definitiva cautelar; e ii) assegurar a futura eficácia da tutela definitiva satisfativa".

Encontra previsão normativa atual no art. 305 do CPC/2015, em que o Réu deverá ser citado para contestar ao pleito autoral no prazo de 5 (cinco) dias, o que é, diga-se de passagem, um dos poucos prazos dispostos no CPC/2015 que "foge" da regra dos 15 (quinze) dias.

Em sequência, como determina o art. 308 deste mesmo diploma processual, o Autor deverá apresentar nos mesmos autos, no prazo de 30 (trinta) dias, o seu pedido principal, sendo, em seguida, as partes intimadas para comparecimento em audiência de conciliação ou de mediação e não sendo possível a composição entre as partes, será iniciado o prazo para o Réu apresentar contestação.

Atenta-se para o fato de que tal procedimento difere dos outros dispostos pelo CPC/2015, inclusive quanto aos prazos e ônus processuais.

\footnotetext{
${ }^{22}$ DIDIER JR. Fredie. Curso de Direito Processual Civil. 10a ed. Editora Juspodim. Salvador. 2015. P. 613
} 


\section{Capítulo 5. DA TUTELA DE EVIDÊNCIA}

\subsection{Regramento e Características}

Uma das maiores novidades do CPC/2015 é, sem dúvida alguma, a tutela provisória de evidência.

Disciplinada no Título III do diploma processual atual, pelos artigos 311 e seguintes, este novo instituto independe da demonstração de perigo ou risco ao resultado útil do processo, sendo cabível apenas nas seguintes hipóteses. Veja-se:

"TÍTULO III

DA TUTELA DA EVIDENNCIA

Art. 311. A tutela da evidência será concedida, independentemente da demonstração de perigo de dano ou de risco ao resultado útil do processo, quando:

I - ficar caracterizado o abuso do direito de defesa ou o manifesto propósito protelatório da parte;

II - as alegações de fato puderem ser comprovadas apenas documentalmente e houver tese firmada em julgamento de casos repetitivos ou em súmula vinculante;

III - se tratar de pedido reipersecutório fundado em prova documental adequada do contrato de depósito, caso em que será decretada a ordem de entrega do objeto custodiado, sob cominação de multa;

$I V$ - a petição inicial for instruida com prova documental suficiente dos fatos constitutivos do direito do autor, a que o réu não oponha prova capaz de gerar dúvida razoável.

Parágrafo único. Nas hipóteses dos incisos II e III, o juiz poderá decidir liminarmente." 
A tutela de evidência é definida por Alexandre Câmara ${ }^{23}$ por ser "tutela provisória, de natureza satisfativa, cuja concessão prescinde do requisito de urgência (art. 311).”

E vai além: "Trata-se, então, de uma tutela antecipada não urgente, isto é, de uma medida destinada a antecipar o próprio resultado prático final do processo, satisfazendo-se na prática o direito do demandante, independentemente da presença do periculum in mora", concluindo que estarse-ia diante, assim, de "uma técnica de aceleração do resultado do processo, criada para casos em que se afigura evidente (isto é, dotada de probabilidade máxima) a existência do direito material”.

Tal definição é comungada por vários outros doutrinadores contemporâneos, sendo unânime no ordenamento jurídico atual que tal instituto deva ser encarado como uma verdadeira técnica processual e não como um tipo de tutela jurisdicional.

Pelo menos é isso que defende Didier ${ }^{24}$ quando aborda, em seu manual de processo civil que, a tutela provisória de evidência deve ser interpretada como um fato jurídico processual, o qual é observado pelo magistrado e, após a verificação de seus requisitos necessários, é concedida de forma antecipada a tutela definitiva (direito material).

Como pressupostos, a Tutela de evidência deve ser amparada na (i) prova das alegações, bem como (ii) na probabilidade o direito.

\footnotetext{
${ }^{23}$ CÂMARA. Alexandre Freitas. O Novo Processo Civil Brasileiro. 1a ed. Atlas. São Paulo.2015. P. 169

${ }^{24}$ DIDIER JR. Fredie. Curso de Direito Processual Civil. 10a ed. Editora Juspodim. Salvador. 2015. P. 617
} 
Importante ressaltar que esse novo instituto acaba por inverter o ônus do tempo nos processos. Isto é, havendo o deferimento da tutela de evidência, caberá ao Réu diligenciar para reverter a decisão judicial que a conceder, uma vez que o Autor já estará de "posse" de seu pretendido direito.

Diante desse raciocínio, pondera-se que a tutela de evidência esteja em plena consonância com a ordem constitucional de duração razoável do processo (CF, art. 5 $5^{\circ}$ LXXVIII), assim como a eficácia da atividade jurisdicional, tornando mais interessante para o tutelado, tendo em vista a resposta rápida do Estado para amparar o seu evidente direito.

Sucede, porém, como bem observado pelo ilustre professor Fredie ${ }^{25}$, são muito raras as hipóteses de sua incidência, ainda mais se tratando da modalidade "punitiva", prevista no inciso I do art. 311, do CPC/2015, uma vez que o Juiz detém armas e instrumentos eficazes para "combater deslealdade processual, para evitar ou reprimir comportamentos ardilosos e meramente protelatórios. É o caso dos arts. 139, III, 77, $\$ 2^{\circ}, 79$ a 81, 774, dentre outros do CPC".

Outro aspecto interessante que deve ser destacado é o fato de que a tutela de evidência sempre será incidental.

Tal afirmativa se justifica pela simples leitura do caput do art. 311, notadamente pela passagem "será concedida independentemente da demonstração de perigo de dano ou de risco ao resultado útil do processo".

\footnotetext{
${ }^{25}$ DIDIER JR. Fredie. Curso de Direito Processual Civil. 10a ed. Editora Juspodim. Salvador. 2015. P.
} 623. 
Como mais um aspecto peculiar, inerente a este novo instituto processual, destaca-se que o legislador estabeleceu tratamento diferente para as hipóteses de incidência da tutela de evidência.

Conforme se observa do parágrafo único do alusivo dispositivo infraconstitucional, percebe-se que o legislador excluiu os incisos I e IV das hipóteses de deferimento liminar.

Ou seja, a contrário sensu, observa-se que mesmo tal instituto não dependendo da demonstração de urgência, ele poderá ser concedido liminarmente, mas sempre de forma incidental, contanto que seja as hipóteses relativas aos incisos II e III.

Com efeito, verifica-se uma lógica na atuação do legislador, no que tange a situações passíveis de causar dano à parte contrária com o deferimento da tutela de evidência, na medida em que necessária a sua intimação e manifestação prévia.

Este é o caso da (i) alegação de abuso de direito de defesa ou manifesto propósito protelatório e (ii) prova dos autos que o réu não oponha prova capaz de gerar dúvida razoável.

Tal raciocínio está condizente com os princípios que regem o Código de Processo Civil de 2015, o qual preza pela plena participação das partes, ampla defesa e contraditório, e ainda, a cooperação (CPC/2015, art. $\left.6^{\circ}\right)$. 


\section{Considerações finais}

Neste trabalho, procurou-se, embora sem esgotar o assunto, demonstrar o novo instituto da Tutela Provisória, mais especificamente as modalidades de Tutela de Urgência e Evidência, com ênfase nas requeridas em caráter antecedente.

Como foi apresentado, merece destaque que, apesar do legislador ter andado bem com a criação deste verdadeiro "microssistema" da Tutela Provisória, acabou por não se atentar quanto aos prazos estipulados nos procedimentos, o que podem vir a causar uma grande insegurança jurídica para o ordenamento, principalmente quanto ao aspecto da estabilidade da tutela provisória requerida em carácter antecedente, de modo que, em determinadas situações, o Juiz poderá não encontrar a resposta na norma legal e terá que interpretar com base nas regas gerais do direito.

No entanto, como se sabe, em se tratando de ordenamento jurídico baseado no civil law, tal "solução" poderá não mais indicada e possivelmente, tal aspecto irá gerar grandes discussões jurisprudenciais, colocando um certo grau de incerteza no direito aplicado.

Diante do exposto e críticas a parte, o presente trabalho monográfico teve enfoque acadêmico no estudo pormenorizado das espécies de tutela provisória de urgência e evidência, assim como todas suas características peculiares, apontando como algo a ser enfrentado pelo ordenamento jurídico brasileiro lacunas legislativas, as quais deverão ser supridas pelos julgadores de modo a evitar a insegurança jurídica. 


\section{Bibliografia}

CÂMARA. Alexandre Freitas. O Novo Processo Civil Brasileiro. 1a ed. Atlas. São Paulo.2015.

CARNEIRO. Athos Gustão. Da Antecipação de tutela. 5 a ed.

DIDIER JR. Fredie. Curso de Direito Processual Civil. 10a ed. Editora Juspodim. Salvador. 2015.

MARINONI, Luiz Guilherme. Antecipção de tutela, 8a ed., 2004.

MITIDIERO. Daniel. Tendência em material de tutela sumária: da tutela cautelar à técnica antecipatória. Revista de Processo. São Paulo: RT, 2011.

ZAVASCKI.Teori Albino. Antecipação de Tutela, $2 a$ ed.. 